\title{
The Role of Market Orientation and Creativity in Affecting the Marketing Performance of Market Traders in Aceh Market Banda Aceh City
}

\author{
Marlizar $^{1}$, Taufik Hidayat Harahap ${ }^{2}$, Mirjan Fajri Alda ${ }^{3}$, Marwiadi $^{4}$ \\ ${ }^{1,4}$ Faculty of Economics, Muhammadiyah University, Aceh, Indonesia \\ ${ }^{2,3}$ Syari'ah Banking STAI Tapaktuan, South Aceh, Indonesia \\ marlizar@unmuha.ac.id,taufikhidayat@gmail.com,mirjanfajri@gmail.com,marwiadi@yahoo.com
}

\begin{abstract}
This study aims to analyze the effect of market orientation and creativity on marketing performance in apparel traders in the Aceh Market in Banda Aceh City. The research sample of 96 respondents with accidental sampling sampling technique. Data collection techniques used were observation and questionnaires. The data analysis technique used multiple linear regression analysis and was treated with the help of SPSS software version 22.0. The results showed that partially market orientation and creativity variables influenced marketing performance. While the creativity variable has no effect. This means that the higher the market orientation will improve marketing performance. Simultaneously market orientation and creativity play a role in marketing performance improvement. To improve marketing performance in Aceh market traders, traders are required to be more creative in marketing their merchandise. The recommendations for further research are expected to be able to add variables such as innovation, competitive advantage, and marketing strategies.
\end{abstract}

\section{Keywords}

market orientation; creativity; marketing performance; Aceh Market

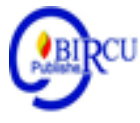

\section{Introduction}

In the current state of the modern economy, conditions have changed, the emergence of competition in the business world is unavoidable. With competition, business people must be more observant in reading opportunities and threats. A business can be successful if it successfully pays attention, retains and grows customers. Basically, the purpose of establishing a company is to get maximum profit. Therefore we need a smooth marketing.

The physical market as a place of concentration of some permanent and non-permanent traders in an open or closed room or a section of road. Furthermore, the retailers grouping occupies buildings with temporary, semi-permanent or building conditions. Market activities are traditional economic activities that have the characteristics of bargaining between sellers and buyers. Creativity has the ability to develop new ideas from ideas that are already owned and sourced from the consumer. Creativity will be to shape useful innovations.

The Aceh Market is one of the modern traditional markets under the management of the Market Technical Implementation Unit (UPTD) of the Market in accordance with Mayor Regulation Number 39 of 2011 concerning the Organizational Structure and Work Procedure of the Market Technical Implementation Unit (UPTD) of the Banda Aceh City Cooperative and SME Trade Industry Office. The Phase I Atjeh Market was inaugurated on May 15, 2009, while the Phase II Atjeh Market was inaugurated by the Indonesian Minister of Trade on July 16, 2013 The Atjeh Market was managed according to the Regional Public Service Board Financial Management Pattern (PPK-BLUD) in accordance with Minister of Domestic Affairs Regulation No. 61 Year 2007 Concerning Technical Guidelines for Financial 
Management of Regional Public Service Agencies (BLUD) Rental Rates and Market Operational Costs in the Atjeh Market Unit are regulated by Banda Aceh Mayor Regulation No. 8 of 2013 concerning Rental Prices and Operating Costs for Shops, Kiosks and Los Atjeh Markets, and in 2016 the Banda Aceh City Mayor Regulation (Perwal) No. 27 of 2016 concerning Amendments to the Regulation of the Mayor of Banda Aceh Number 8 of 2013 concerning Rental Prices and Operational Costs for Aceh Shops, Kiosks and Los Markets.

The location of Aceh Market is very strategic because it is located in the heart of Banda Aceh City. Aceh Market is like a modern market, selling facilities at Aceh Market are also built with the current concept. Besides providing hundreds of stalls on each floor, "Aceh Market is indeed a modern market, but it remains a traditional market owned by the community. The Aceh Market Complex will also be equipped with escalator facilities or road stairs that facilitate links between floors 1,2 and 3. And will also be equipped with shopping centers, hawker centers, and mushallas and meeting rooms. With this more established facility, Aceh Market traders are asked to comply with all the provisions that have been regulated in controlling and managing the market. there are two interesting things from the development of the Aceh Market, the first is that the building of this market is not on empty land owned by the Banda Aceh City Government in full, but on land owned by the community, private, family, waqaf land and partly owned by the City Government with land consolidation system. "While the second, Pemko has authorized the management of this market with the Regional Public Service Agency system,"

Based on an initial survey of 96 apparel traders in the Aceh Market in the city of Banda Aceh, shows that it tends to be empty of buyers. This is due to the fact that the customers who are generally middle-income people down with erratic settlements and also customers prefer markets / malls that are more modern and have more complete facilities that provide comfort when they are in the neighborhood, besides modern markets such as Suzuya Mall, and Hermes Matahari The mall also offers discont prices that are very promising to customers so that customers prefer a more modern market than Aceh Market. this has an impact on the low interest of people shopping at the Aceh Market. In summary, the results of the initial survey can be seen from the results of the distribution of the questionnaire in table 1.1. following:

Table 1. Results of an initial survey of marketing performance Clothing traders become the Aceh market

\begin{tabular}{|c|l|c|c|c|}
\hline No & \multicolumn{1}{|c|}{ Marketing Performance } & Yes & No & Total \\
\hline 1 & $\begin{array}{l}\text { The sale of apparel continues to increase from time } \\
\text { to time }\end{array}$ & $\begin{array}{c}35 \\
(36,5 \%)\end{array}$ & $\begin{array}{c}61 \\
(63,5 \%)\end{array}$ & $\begin{array}{c}96 \\
(100 \%)\end{array}$ \\
\hline 2 & Customers who come and buy continue to grow & $\begin{array}{c}40 \\
(42 \%)\end{array}$ & $\begin{array}{c}56 \\
(58 \%)\end{array}$ & $\begin{array}{c}96 \\
(100 \%)\end{array}$ \\
\hline 3 & The profit you get from sales continues to increase & $\begin{array}{c}44 \\
(46 \%)\end{array}$ & $\begin{array}{c}52 \\
(54 \%)\end{array}$ & $\begin{array}{c}96 \\
(100)\end{array}$ \\
\hline
\end{tabular}

Source: Initial Survey Results (2018)

From table 1 above, we can see three questions raised by the author of 96 apparel traders in the Aceh banda Aceh market. The first question related "The results of the sale of apparel continues to increase from time to time" 35 traders stated agree (36.5\%) and 61 traders stated disagree $(63.5 \%)$. Then the second question related "Customers who come and buy continue to grow" 40 merchants said they agreed (42\%) and 56 traders said they did not 
agree $(58 \%)$. Then the last question related "The profit you get from sales continues to increase" 44 traders stated agree (46\%) and 52 traders stated disagree $(54 \%)$.

The problem above, of course, shows the marketing performance of apparel traders is not good, where from time to time the marketing of apparel traders is compared from previous years. This is certainly a problem for traders if left unchecked will have an impact on the sustainability of the problem itself, so we need factors that can drive marketing performance in apparel traders.

Many factors affect marketing performance, including customer orientation, market orientation, and competitive strategy. Oriented which involves willingness to bind resources and dare to face challenges by exploiting or engaging in business strategies where the possible outcome is full of uncertainty (Novitasari \& Zuraida, 2015: 167).

Based on the background of the aforementioned research, the formulation of the problem of this study is how big is the role of market orientation and creativity in influencing the marketing performance of apparel traders in the Banda Aceh City Aceh market.

\section{Review of Literature}

\subsection{Marketing Performance}

According to Tjiptono (2011) marketing performance is a function that has the greatest contact with the external environment, even though the company only has limited control over the company's environment. Performance is the result that has been achieved from what has been done by the owner or manager in running the business. Marketing performance can be measured by using sales growth, customer growth and product success to measure the impact of the strategy adopted by the company. The company's strategy is always directed to produce good marketing performance and also good financial performance. The company's strategy is always directed to produce good marketing performance and also good financial performance because the business objectives besides creating customers, are also able to get profits.

\subsection{Marketing Performance Indicators}

The implementation of marketing strategy as reported by (Nuseir and Madanat 2015) would end in a positive impact to the customers, as long as the procedures meet the standards. The similar result was also reported by (Londhe in Kusumadewi, 2019) which showed that marketing association was referred to an instrument for marketing and deemed to have a positive impact upon the enhancement on the customer value.

According to Ferdinand (2000: 125) in Nasution (2014: 3) indicators of good marketing performance are stated in four main quantities, namely: sales volume, number of customers, profits, and also sales growth which ultimately leads to corporate profits.

1. Sales volume shows the rupiah or how much the unit is sold.

2. The number of customers shows the progress of a business or an increase in sales.

3. Profits indicate the success or success of an attempt to increase profits.

4. Sales growth shows how much sales contribution dominates the market.

\subsection{Market Orientation}

Market orientation is important for companies in line with increasing global competition and changes in customer needs where companies realize that they must always be close to their markets. Market orientation is a business culture where the organization has a commitment to continue to be creative in creating superior value for customers. On one hand, market orientation can reveal the limitations of new products, which allows redesign 
actions, but also causes negative feedback on truly innovative products. Emphasis on market orientation which leads to slight product modification can have a positive impact on new product development.

\subsection{Dimensions of Market Orientation}

Market orientation is the most effective and efficient organizational culture in creating the behavior needed to create superior value for customers so that it can produce superior business performance on an ongoing basis. Market orientation includes three dimensions namely Taleghani, et al. (2013).

1. Customer orientation which consists of customer analysis and response to customers.

2. Competitor orientation which consists of competitor analysis and challenging reactions to competitors,

3. Inter-functional coordination consisting of disseminating information, collecting data and utilizing information.

Market orientation is an organizational perspective that encourages three main aspects namely (Nuvriasari, et al., 2015: 243):

\subsection{Market Orientation Indicator}

Some indicators used to measure market orientation are customer orientation, competitor orientation, and market information. Narver and Slater as quoted by Alam (2013) Market orientation as a one-dimensional construct consists of 3 behavioral components, namely customer orientation, competitor orientation and coordination between inter-firm functions (interunctional coordination).

Fandy Tjiptono and Gregorius Chandra (2012), stated that market orientation consists of 3 indicators namely customer orientation, competitor orientation and coordination between functions

1. Customer orientation, in this case related to customer commitment, customer value creation, and understanding customer needs.

2. Competitor orientation, in this case, has to do with reacting quickly to competitors' actions, targeting opportunities in competitive advantage.

3. Coordination between functions, in this case relating to the provision of information for customers and customer contact between functions.

\subsection{Creativity}

Creativity is an initiative to a product or process that is useful, true, appropriate and valuable to a task that is more heuristic, that is something that is a guide, guide, or incomplete guide that will lead us to understand, learn, or discover something new Hadiyati , (2011). The creativity of a marketing program is an extension of the actions taken to market a product that illustrates the meaningful differences from marketing implementation. Liany (2003: 17) in Sitohang, S. (2017).

\subsection{Factors That Influence Creativity}

Creativity can be seen from several factors. Creativity factors are the constituent components of creative action. Basically humans have the potentials to be creative, depending on how to develop and grow the creative potential, the characteristics of creative individuals are imaginative, have initiative, have broad interests, are free to think, strong curiosity, want to get new experiences, full of enthusiasm and energetic, confident, willing to take risks and brave in opinion and have self confidence. 


\subsection{Indicator of creativity}

Creativity refers to mental processes that involve the emergence of new ideas or ideas, or new relationships between ideas and existing ideas. indicator of creativity that has a low percentage value, namely the indicator of the emergency of new ideas, where this is seen in the low knowledge of the sword in carrying out marketing strategies to approach consumers, the low level of adoption of a down payment system for customers and providing a minimum discoun- ting spending with a certain nominal and the lack of traders in interacting with consumers. namely:

According to Hadiyati (2011) indicators of creativity can be seen from four aspects,

1. Use new ideas to attract customer interest.

2. Pursuing opportunities to increase sales value.

3. Having freedom of thought so that you can think more creatively.

4. Initiative and appropriate decision making.

\subsection{Framework}

Based on the literature review and also previous research, a framework of thought in this study can be arranged as presented in the following figure:

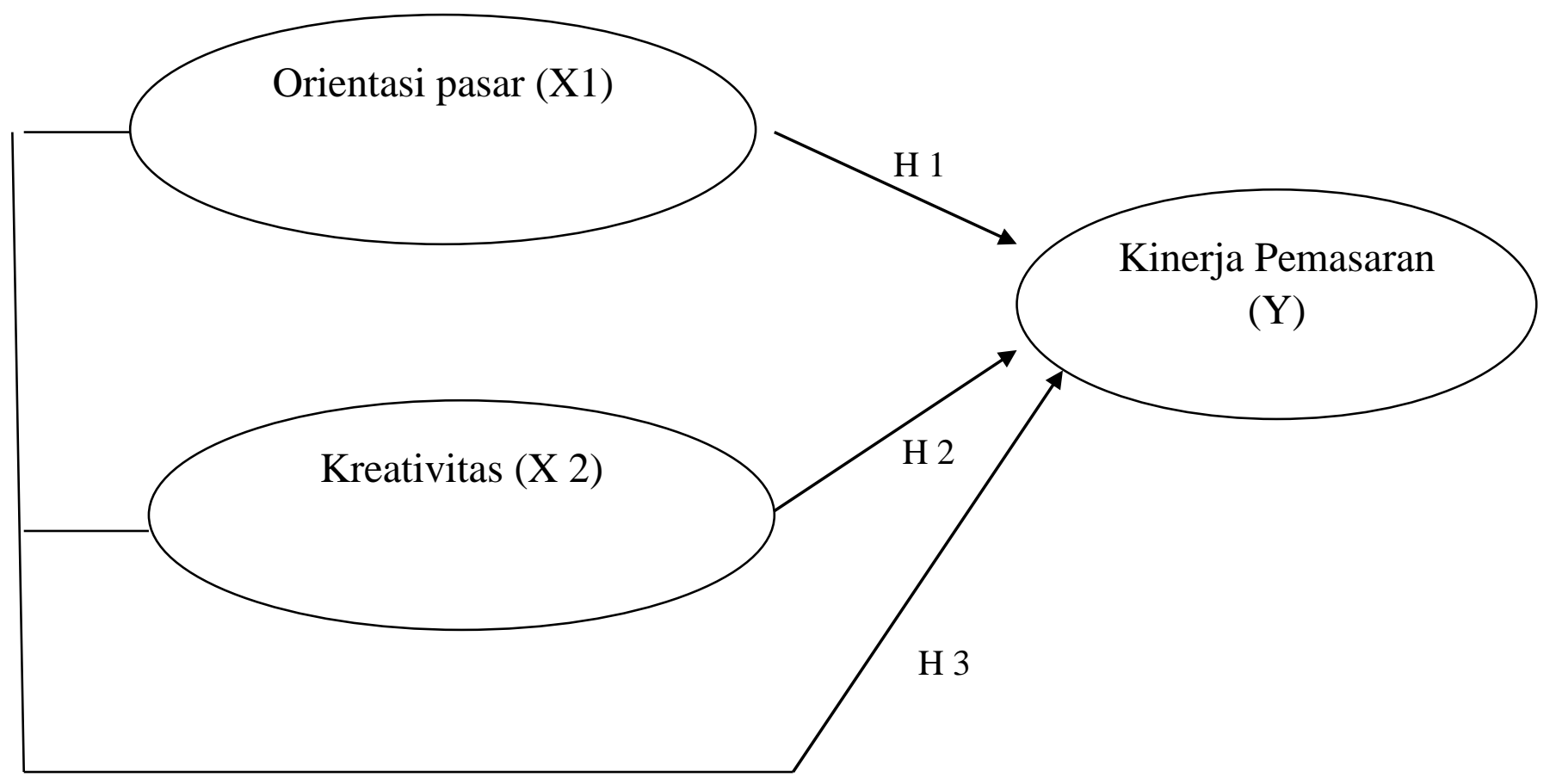

Figure 1. Framework Paradigm

Source: Theoretical review and previous research (2018)

Research Hypothesis

Based on the theoretical review, previous research, and the above frame of mind, the hypotheses in this study are as follows:

Ha1: There is a significant influence of Market orientation on the marketing performance of apparel traders in the Banda Aceh Aceh market.

Ha2: There is a significant effect of marketing creativity on Marketing Creativity in apparel traders in the Banda Aceh Aceh market. 
Ha3: joint marketing performance is influenced by Market Orientation and Marketing Creativity for apparel traders in the Banda Aceh Aceh market.

\section{1 Research design}

\section{Research Method}

This type of research is associative. Where this type of associative research is to analyze the effect or relationship between independent variables on the dependent variable. Both together (simultaneously), and individually (partial).

\subsection{Population and Sampling Techniques}

The population in this study is clothing traders in the Banda Aceh Aceh Market whose numbers are not known with certainty. Therefore, the population in this study is all apparel traders in the Banda Aceh Aceh market whose numbers are not known with certainty.

The sampling technique in this study is non probality sampling with the type of purposive sampling, namely sampling based on predetermined criteria. Respiratory criteria are set as follows:

1. Clothing traders in the Banda Aceh Aceh market.

2. Have been trading for more than 1 year.

3. Minimum age of 20 years.

The determination of the number of samples in this study uses the formula according to the primordial in Widiyanto (2012) as stated below:

Where:

$$
n=\frac{Z^{2}}{4(M o e)^{2}}
$$

$\mathrm{n}=$ number of samples

$\mathrm{Z}=$ normal level of distribution at a significant level of $5 \%=1.96$

Moe $=$ The maximum margin of error is $10 \%$ or 0.1

By using a margin of error of $10 \%$, the minimum number of samples that can be taken is:

$n=\frac{(1,96)^{2}}{4(0,10)^{2}}=\frac{3,84}{4(0,01)}=\frac{3,84}{0,04}=96,04$

$\mathrm{n}=96.04$ rounded to 96

Based on the calculation results, the number of samples to be used was 96 respondents.

\subsection{Scale of Measurement}

Research data obtained through questionnaire questions in the form of qualitative are composed in advance to become quantitative data. The quantitative values compiled are performed using a Likert Scale and for one choice assessed (Score) with an interval of 1. The scores (Score) of the choices include 1, 2, 3, 4 and 5. Each value of the choice can be seen the following :

Table 2. Scale of measurement

\begin{tabular}{|c|c|}
\hline Description (Optional) & Score \\
\hline Strongly disagree & 1 \\
\hline Disagree & 2 \\
\hline Not agree & 3 \\
\hline Agree & 4 \\
\hline Strongly agree & 5 \\
\hline
\end{tabular}

Source: Arikunto (2013) 


\subsection{Technique of analysis Data}

The data analysis technique used in this study is multiple linear regression analysis which is assisted by statistical data processing applications, namely SPSS version 22 . According to Widodo (2016: 9) multiple linear regression analysis is used to measure the effect of variables involving more than one independent variable with respect to the dependent variable. The results of multiple linear regression analysis will determine whether the hypothesis made is accepted will be rejected. The methods used are data testing, hypothesis testing (simultaneous significant test $\mathrm{f}$ and significant test individual parameter $\mathrm{t}$ ) and coefficient of determination R2. Multiple linear regression analysis was used to examine the role of market orientation and creativity on marketing performance in apparel traders in the Aceh banda Aceh market. The results of this multiple linear regression analysis will determine whether the hypothesis made is accepted or rejected.

The equations of the multiple linear regression models in this study are as follows:

$$
\begin{aligned}
& \mathrm{Y}=\mathrm{a}+\mathrm{b} 1 \mathrm{X} 1+\mathrm{b} 2 \mathrm{X} 2+\mathrm{e} \\
& \text { Information : } \\
& \mathrm{Y} \quad=\text { Marketing Performance } \\
& \mathrm{a} \quad=\text { constant } \\
& \mathrm{b} 1, \mathrm{~b} 2=\text { coefficient } \\
& \mathrm{X} 1 \quad=\text { Market Orientation } \\
& \mathrm{X} 2 \quad=\text { Creativity } \\
& \mathrm{e} \quad=\text { error term }
\end{aligned}
$$

\subsection{Definition of Variable Operations}

The operational definition of a variable is the meaning expressed in the concept, operationally, practically, significantly in the environment of the research object or object being studied. The variables used in this study are the independent variables and the dependent variable.

a. Independent variable (Independent variable)

Is an influencing variable, which causes the emergence or change of a bound variable.

b. Dependent Variable (Dependent Variable)

Is the variable that is affected because of the independent variables. As for the operational variables in this study, consisting of independent variables namely Market Orientation (X1) and Creativity (X2) and the dependent variable marketing performance (Y) The details of operational variables can be seen in the following matrix:

\subsection{Validity test}

Validity test is done by using confirmatory factor analysis on each latent variable. Indicators of a variable are said to be valid if they have significant loading factors at $(\alpha=$ $5 \%$ ). The research instrument is valid unidimensional if it has a value of goodness of fit index (GFI)> 0.90. Ulum, (2013: 28).

\subsection{Reliability Test}

The reliability test shows the extent to which a tool can provide relatively the same results when measuring back on the same subject. The boundary value used to assess an acceptable level of reliability is 0.70 , even though that number is not a measure of death (Ulum, 2013: 28). 


\section{Discussion}

\subsection{Characteristics of Respondents}

Respondents in this study were apparel traders in Banda Aceh Aceh Market. The number of respondents was 96 people with characteristics based on gender, education, length of entrepreneurship, marital status and income. The characteristics of the demographic classification of respondents are set out in the following table 3 :

Tahle 3. Validitv Test Results

\begin{tabular}{|c|c|c|c|c|c|}
\hline \multicolumn{2}{|c|}{ No question } & Variable & $\begin{array}{c}\text { Koefisien } \\
\text { korelasi }\end{array}$ & $\begin{array}{l}\text { Nilai Kritis } \\
5 \%(\mathrm{~N}=96)\end{array}$ & \multirow{2}{*}{$\begin{array}{l}\text { Inform } \\
\text { Vamo } \\
\text { Valid }\end{array}$} \\
\hline 2 & A2 & \multirow{3}{*}{$\mathrm{Y}$} & 0,398 & & \\
\hline 3 & A3 & & 0,573 & 0,202 & Valid \\
\hline 4 & A4 & & 0,463 & 0,202 & Valid \\
\hline 5 & B1 & \multirow{3}{*}{$\mathrm{X} 1$} & 0,477 & 0,202 & Valid \\
\hline 6 & B2 & & 0,398 & 0,202 & Valid \\
\hline 7 & B3 & & 0,549 & 0,202 & Valid \\
\hline 8 & $\mathrm{C} 1$ & \multirow{4}{*}{$\mathrm{x} 2$} & 0,424 & 0,202 & Valid \\
\hline 9 & $\mathrm{C} 2$ & & 0,364 & 0,202 & Valid \\
\hline 10 & C3 & & 0,421 & 0,202 & Valid \\
\hline 11 & $\mathrm{C} 4$ & & 0,330 & 0,202 & Valid \\
\hline
\end{tabular}

Source: data processed (2018)

Based on table 4. can be explained that all the variables used in this study were declared valid, so that all questions contained in this research questionnaire were declared valid to proceed to more in-depth research, because the validity value obtained was greater than the critical value Product moment of 0.202 at the significance level $\alpha=5 \%$, so that the data instrument is worthy of further discussion.

\subsection{Reliability Test Results}

To assess the reliability of a questionnaire used, this study uses a reliability test based on Cronbach Alpha which is commonly used for testing questionnaires in social science research. This analysis is used to interpret the correlation between the scale created with the

scale of existing variables. Malhotra (2014: 268) states, the acceptable cronbach alpha coefficient or value is above 0.60 . For more clearly the value of alpha in each variable is shown in the following table:

Table 4. Reliability test results

\begin{tabular}{|l|l|c|c|c|}
\hline No & Variable & Variable Items & Alpha value & Reliability \\
\hline 1 & Marketing performance (Y) & 4 & 0,664 & Reliable \\
\hline 2 & Market Orientation (X1) & 3 & 0,660 & Reliable \\
\hline 3 & Creativity & 4 & 0,604 & Reliable \\
\hline
\end{tabular}

Based on table . above the reliability test of the attribute questions involved in each variable Marketing Performance (Y) Market Orientation (X1) and creativity (X2) as shown in table 4.3 obtained alpha each of 0.664. 0.660. and 0,604. Thus the values of the attributes involved in the measurement of these variables meet the Cronbach alpha credibility because the alpha value exceeds 0.60 . 


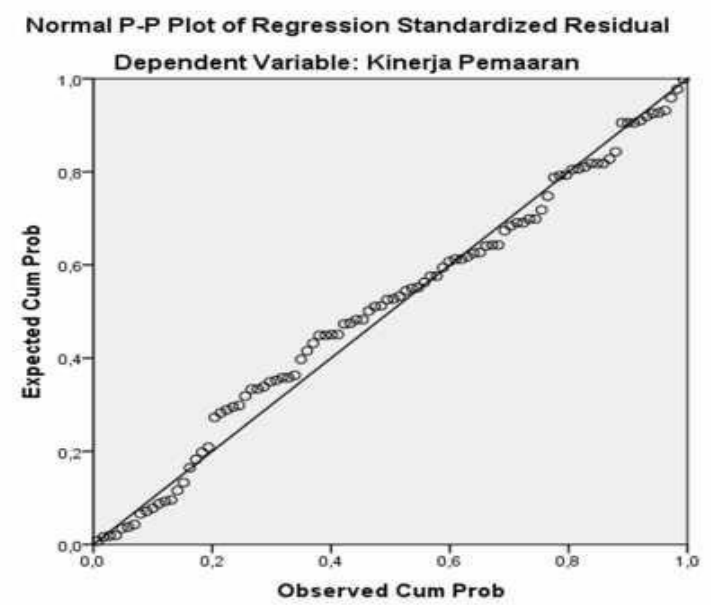

Figure 2

From Figure 2. The normal probability plot above shows the normal distribution pattern, the data spreads around the diagonal line and follows its direction so it can be concluded that the normality assumption has been fulfilled.

Apart from looking at graphs, assuming normality can also use the komlogorovsmirnov test. In this test the data is said to be normally distributed if the significance value of komlogorov-smirnov is greater than the predetermined significance value of 0.05 .

Table 5. Kolmogorov-smirnov test

One-Sample Kolmogorov-Smirnov Test

\begin{tabular}{|c|c|c|}
\hline & & $\begin{array}{l}\text { Unstandardized } \\
\text { Residual }\end{array}$ \\
\hline \multicolumn{2}{|l|}{$\overline{\mathrm{N}}$} & 96 \\
\hline \multirow{2}{*}{ Normal Parameters ${ }^{a, b}$} & Mean &, 0000000 \\
\hline & $\begin{array}{l}\text { Std. Deviation } \\
\text { Absolute }\end{array}$ & $\begin{array}{r}, 50044343 \\
073\end{array}$ \\
\hline \multirow[t]{2}{*}{ Most Extreme Differences } & Positive &, 049 \\
\hline & Negative &,- 073 \\
\hline Kolmogorov-Smimov Z & &, 718 \\
\hline Asymp Sig. (2-tailed) & &, 681 \\
\hline
\end{tabular}

Frı b. Calculated from data.

$I$ can be

said to be normal because the value of asymptotic significance is 0.681 greater than the significance value that has been set at 0.05 .

\subsection{Multicollinearity Test}

Table 6. Tolerance Value and VIF Coeffiecets

\begin{tabular}{|l|c|c|}
\hline \multirow{2}{*}{ Model } & \multicolumn{2}{|c|}{ Collinearity Statistics } \\
\cline { 2 - 3 } & Tolerance & VIF \\
\hline (Constant) & & \\
1 Market orientation &, 895 & 1,117 \\
Creativity &, 895 & 1,117 \\
\hline
\end{tabular}


a. Dependent Variable: Marketing performance

Based on table 6. above, it can be seen the tolerance value and VIF for each variable is $0.895>0.10$ and $1.117<10$. Then it can be stated that there are no symptoms of multicollinearity on these variables.

\subsection{Heteroscedasticity Test}

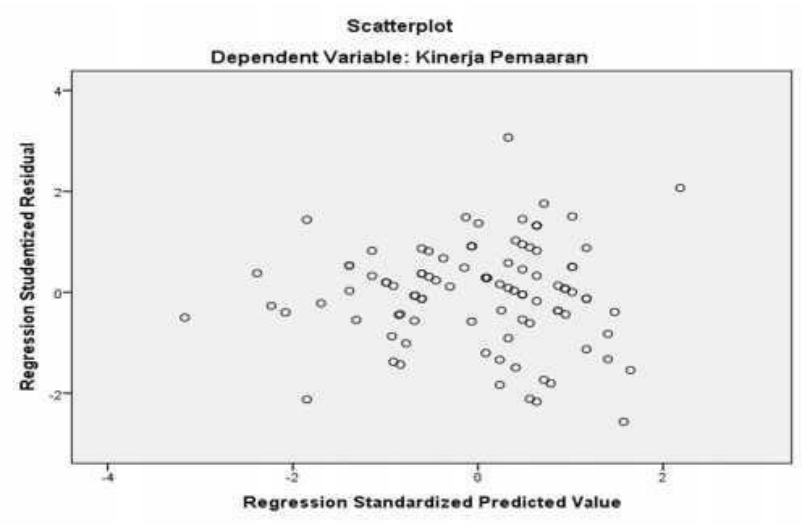

Figure 3

Scatterplot graph in Figure 3. Does not show a particular shape or pattern. Visible point spread randomly and evenly on the $\mathrm{X}$ axis or $\mathrm{Y}$, it can be concluded that there was no heteroscedaticity problem in the linear regression model.

\subsection{Hypothesis test}

The hypothesis states that Market Orientation (X1) and Creativity (X2). As a variable contributes to the Marketing Performance of apparel traders in the Aceh Market in Banda Aceh City. The model used to predict this role is:

Table 7. The role of the independent variable on marketing performance At the Aceh apparel market trader in the city of Banda Aceh

\begin{tabular}{|l|l|l|l|l|c|}
\hline \multicolumn{1}{|c|}{ Variable Name } & B & Std Error & $t_{\text {count }}$ & $t_{\text {table }}$ & Sig \\
\hline A constant & 0,572 & 0,348 & 1,644 & 2,202 & 0,104 \\
\hline Market Orientation $(\mathrm{X} 1)$ & 0,491 & 0.076 & 6,422 & 2,202 & 0,000 \\
\hline Creativity $(\mathrm{X} 2)$ & 0,257 & 0,099 & 2,599 & 2,202 & 0,011 \\
\hline
\end{tabular}

Source: process data (2018)

Based on the results of computer output through the SPSS program as shown in the table above, the multiple linear regression equation is obtained as follows:

$\mathrm{Y}=0,572+0,491 \mathrm{X} 1+0,257 \mathrm{X} 2$

From the regression equation above, it can be seen the results of the study as follows:

1) Regression Coefficient $(\beta)$

- In the research, the constant value is 0.572 , which means that if the Market Orientation (X1) and Creativity (X2), are considered constant, then the Marketing Performance of ready-to-wear clothing traders in the Aceh market in Aceh, Aceh, is 0.572 on the Likert scale. 
- Market Orientation (X1) regression coefficient of 0.491 . This means that every $100 \%$ change in the Market Orientation variable will contribute to the Marketing Performance of the Clothing Trader in Aceh Market in the city of Aceh banda as much as $49.1 \%$ with the assumption that the Creativity (X2) variable is considered constant.

- Creativity regression coefficient (X2) of 0.257 . This means that every $100 \%$ change in the creativity variable will relatively contribute to the Marketing Performance of the Apparel Trader in the Aceh Market in the city of Banda Aceh by $25.7 \%$ assuming the Market orientation variable (X1) is considered constant

Based on the results of the above analysis it can be seen that from the two variables studied it turns out that Market orientation variables have a dominant role in improving Marketing Performance in Clothing Traders in Aceh Market in the city of Banda Aceh because a regression coefficient of $49.1 \%$ is obtained.

\subsection{Correlation Coefficient ( $R$ ) and Determination Coefficient ( $R 2)$}

To find out how much an increase in linear can be explained through the relationship between variables (correlation). If all the values of these variables can satisfy an equation correctly, then it can be said that there is a perfect correlation in this analysis model. From the SPSS version 22 output it can be seen the degree of relationship between the independent variable and the dependent variable between other variables.

Table 8. Koefesien determinasi model summary

\begin{tabular}{|c|c|c|c|c|}
\hline Model & $\mathrm{R}$ & $\mathrm{R}$ Square & $\begin{array}{c}\text { Adjusted R } \\
\text { Square }\end{array}$ & $\begin{array}{c}\text { Std. Error of the } \\
\text { Estimate }\end{array}$ \\
\hline 1 &, 643 &, 414 &, 401 &, 50580 \\
\hline
\end{tabular}

a. Predicators: (Constant), CREATIVITY, MARKET ORIENTATION

Based on the analysis of SPSS data version 22 above, a correlation coefficient of 0.643 is obtained, which means that there is a relationship between the independent variable and the dependent variable of 0.643 or $64.3 \%$. Meanwhile the coefficient of determination obtained with a value of 0.401 means that $40.1 \%$ of changes in the Marketing Performance (Y) dependent variable can be explained by changes in Market Orientation (X1) and Creativity (X2) factors. While the remaining $59.9 \%$ is explained by other factors beyond the two variables as explained above.

\subsection{Simultaneous F Test (F test)}

The $\mathrm{F}$ test shows whether all independent variables (entrepreneurial orientation, market orientation, and competitive strategy) included in this research model have a joint influence on the dependent variable (marketing performance). The results of the $\mathrm{F}$ test analysis can be seen in table 9.

Table 9. Hasil Uji F (Simultan) ANOVA

\begin{tabular}{|l|r|r|r|r|r|}
\hline \multicolumn{1}{|c|}{ Design } & Sum of Squares & df & Mean Square & F & Sig \\
\hline \multicolumn{1}{|c|}{ Regression } & 16,796 & 2 & 8,398 & 32,826 &, $000^{\circ}$ \\
1 Residual & 23,792 & 93 &, 256 & & \\
Total & 40,588 & 95 & & & \\
& & & & & \\
& & & & & \\
\hline
\end{tabular}


a. Dependent Variable: Marketing performance

b. Predictors: (Constant), Creativity, market orientation

Source: Process data $(2018$

From table 9 above, the $\mathrm{F}$ (simultaneous) test results in this study can be described as follows:

1. The table above shows the significance value of 0,000 which means it is smaller than 0.05 . This shows that all independent variables namely market orientation, and creativity have a significant and simultaneous significant effect on marketing performance.

2. The Fcount value is known to be 32.826 with a Ftable value of 3.094. it shows Fcount> Ftable which means $\mathrm{Ha}$ is accepted and $\mathrm{HO}$ is rejected. Thus the independent variables (market orientation, and creativity) together influence the dependent variable (marketing performance).

\subsection{Partial t-test (Individual)}

$\mathrm{T}$ test (partial) is conducted to determine whether each independent variable (market orientation and creativity) significantly influences the dependent variable (marketing performance). This test is done by comparing the value of tcount with ttable. The hypothesis to be tested is $\mathrm{H} 0$ : bi $=0$, meaning that an independent variable has no influence on the dependent variable. Ha: bi> 0, meaning that an independent variable has an influence on the dependent variable with the terms tcount $>\mathrm{t}$ table, then $\mathrm{Ha}$ is accepted if $\mathrm{t}$ count $<\mathrm{t}$ table then $\mathrm{Ha}$ is rejected. Therefore this test is used to test the hypotheses H1, H2, H3. The following is a table showing the results of the $t$ test and the magnitude of $t$ table at the significance of $5 \%$ two sides, this can be seen in table 10. Following :

Table 10. $\mathrm{T}$ Test Results (partial)

\begin{tabular}{|l|l|l|l|}
\hline No & Hipotesis & \multicolumn{1}{c|}{ Score } & Decision \\
\hline 1 & $\begin{array}{l}\text { Market orientation variable influences } \\
\text { marketing performance }\end{array}$ & $\begin{array}{l}\text { tcount }=6,442 \\
\text { ttable }=1,986 \\
\text { Sig }=0,000\end{array}$ & Accept Ha \\
\hline 2 & $\begin{array}{l}\text { Creativity variable influences marketing } \\
\text { performance }\end{array}$ & $\begin{array}{l}\text { tcount }=2,599 \\
\text { ttable =1,986 } \\
\text { Sig }=0,011\end{array}$ & Accept H a \\
\hline
\end{tabular}

From the table above, the t-test results in this study can be explained as follows:

1. H1: Market orientation variables play a role in the marketing performance of apparel traders in the Banda Aceh Aceh Market. The table above shows the Market Orientation variable (X1) has a significance value of 0,000 , which means it is smaller than 0.05 with a tcount of 6.422 and a table value of 1.986 ( $t$-count $>t$-table). The results of the regression analysis show that market orientation plays a role in the marketing performance of apparel traders in the Aceh Aceh Banda Aceh Market, which means H1 is accepted and H0 is rejected.

2. H2: Creative variables do not contribute to the marketing performance of apparel traders in the Banda Aceh Aceh Market.

The table above shows the creativity variable has a signinfication value of 0.011 , which means it is greater than 0.05 with a t-value of 2.599 and a table value of 1.968 (t-count <ttable). The results of the regression analysis show that creativity plays a role in the marketing 
performance of apparel traders in the Banda Aceh Aceh Market, which means H2 is rejected and $\mathrm{HO}$ is accepted.

\section{Conclusion}

Based on the results of the discussion above, the following conclusions can be drawn:

1. Simultaneously or together market orientation and creativity contribute to the marketing performance of apparel traders in the Banda Aceh City Aceh market. This means that the higher the market orientation will improve marketing performance.

2. Partially market orientation plays a role in the marketing performance of apparel traders in the Banda Aceh City Aceh market. This means that the higher the market orientation will improve marketing performance.

3. Partially creativity does not contribute to the marketing performance of apparel traders in the Banda Aceh City Aceh market. This is due to traders who are less creative in providing and marketing their merchandise, of course this research is different from previous research conducted by Adijati Utaminingsih (2016) where the results of her research stated creativity has an influence on marketing performance in the small and medium industries of rattan handicraft in Teluk Wetan Village, Welehan District Jepara Regency.

\section{References}

Alam, M.M., (2013), Effect of Market Orientation on Small Business Perormance in SmallTown In Malaysia: An Emprical Study on Malaysian Small Firms, Journal of Strategic Marketing, Vol 1, No. 3.

Andari, N. M., Widodo \& Sriyadi (2016). Consumer Preference Towards Organic Vegetables At Super Indo Sultan Agung Yogyakarta. Proceeding International Conference Agribusiness Development ForHuman Welfare. 2016. Yogyakarta.

Anzar, S. F., \& Mardhatillah, M. (2018). Analisis Kesulitan Belajar Siswa Pada Pembelajaran Bahasa Indonesia di Kelas V SD Negeri 20 Meulaboh Kabupaten Aceh Barat Tahun Ajaran 2015/2016. Bina Gogik: Jurnal Ilmiah Pendidikan Guru Sekolah Dasar, 4(1).

Fandy, T., Chandra, G., \& Adriana, D. (2012). Pemasaran strategik. Yogyakarta: Andi.

Hadiyati, E. (2011). Kreativitas dan inovasi berpengaruh terhadap kewirausahaan usaha kecil. Jurnal Manajemen dan Kewirausahaan, 13. Vol.1, No.8-16.

Hatta, I. H. (2015). Orientasi Pasar, Orientasi Kewirausahaan, Kapabilitas Pemasaran dan Kinerja Pemasaran. Jurnal Aplikasi Manajemen, 13 Vol4, No.653-661.

Kotler Philip, dan Gary Amstrong (2012). Principles OfMarketing, Global Edition, 14 Edition, Pearson Education.

Kusumadewi, R. (2019). The Role of Marketing and Individual Environment Association in Elevating the Customer Value. Budapest International Research and Critics Institute (BIRCI-Journal), p. 451-460.

Lapian, A. A., Massie, J., \& Ogi, I. (2016). Pengaruh Orientasi Pasar Dan Inovasi Produk Terhadap Kinerja Pemasaran Pada PT. BPR Prisma Dana Amurang. Jurnal EMBA: Jurnal Riset Ekonomi, Manajemen, Bisnis dan Akuntansi, Vol. 4. No.1.

Maholtra, K. Naresh. (2014). Riset Pemasaran, Pendekatan Terapan Edisi Bahasa Indonesia. Jilid 1, Jakarta: PT. Indeks.

Maima, R K., \& Widiyanto, I. (2012). Analisis Pengaruh Kepercayaan Pelanggan Dan Kualitas Pelayanan Terhadap Sikap Pelanggan Dan Implikasinya Terhadap 
Keputusan Pembelian Ulang (Studi Kasus Pada CV. Mukti Manunggal Semarang) (Doctoral dissertation, Fakultas Eonomika dan Bisnis).

Mardhatillah, M., Verawati, V., Evianti, E., \& Pramuniati, I. (2019). BAHAN AJAR INTERAKTIF BERBASIS KEARIFAN LOKAL MELALUI PENDEKATAN SAINTIFIK PADA PEMBELAJARAN BAHASA INGGRIS. Genta Mulia: Jurnal Ilmiah Pendidikan, 10(1).

Moeheriono. (2012). Pengukuran Kinerja Berbasis Kompetensi. Jakarta : Rajawali Press

Munandar, U. (2012). Pengembangan Kreativitas Anak Berbakat. Jakarta: Rineka Cipta.

Nasution, A. A.(2014). Analisis Kinerja Pemasaran PT Alfa Scorpii Medan. Jurnal Riset Akuntansi \& Bisnis, Vol.14. No.1.

Novitasari, D., \& Zuraida, L. (2015). Pengaruh Orientasi Kewirausahaan dan Kompetensi Wirausaha Terhadap Daya Saing. Jurnal Riset Manajemen Sekolah Tinggi Ilmu Ekonomi Widya Wiwaha Program Magister Manajemen, 2. Vol.2, No.165-178.

Nuvriasari, A., \& As'ari, H. (2015). Penerapan Sistem Informasi Keuangan dan Database Pelanggan Guna Mendukung Peningkatan Kinerja UKM. In Prosiding Seminar Nasional \& Internasional.

Sari, L. F. (2013). Pengaruh Orientasi Pasar Dan Kreativitas Terhadap Kinerja Pemasaran Pedagang Pakaian Jadi di pasar Kliwon Kabupaten Kudus. Management Analysis Journal, Vol.2. No.1

Setiawan, H. (2012). Pengaruh Orientasi Pasar, Orientasi Teknologi dan Inovasi Produk Terhadap Keunggulan Bersaing Usaha Songket Skala Kecil di Kota Palembang. ORASI BISNIS, Vol.8 No.2.

Singgih Santoso (2011). Struktural Equation Modeling (SEM) Konsep dan Aplikasi dengan AMOS 18. Jakarta: Elex Media Komputindo Kompas Gramedia.

Sitohang, S. (2017). Pengaruh kreativitas dan trade exhibition terhadap inovasi berkelanjutan dan kinerja pemasaran sentra industri kecil mebel kayu di kabupaten Madiun. Ekuitas (Jurnal Ekonomi dan Keuangan), 12Vol.3. No, 295-319.

Sugiyono. (2014), Metode Penelitian Kuantitatif Kualitatif dan R \& D, Penerbit Alfabeta Bandung. Bandung.

Sumarwan, Ujang dkk (2011), Riset Pemasaran dan Konsumen : Panduan Riset dan Kajian Kepuasan, Perilaku Pembelian, Gaya Hidup, Loyalitas dan Persepsi Resiko, PT Penerbit IPB Press, Bogor.

Sumekar, Y., Riswandi, D., \& Hidayat, D. (2017). Pengaruh Herbisida Atrazine+ Nicosulfuron Terhadap Pengendalian Gulma dan Hasil Tanaman Jagung (Zea mays L.). Agrivet Journal, Vol.5. No.2.

Taleghani, Mohammad, et al. (2013) . A review into thermal comfort in buildings." Renewable and Sustainable Energy Reviews No.26, No. 201-215.

Tjiptono, Fandy. (2011). Service Quality and Satisfaction. Edisi 3. Andi Offset. Yogyakarta.

Ulum, Ihyaul. (2013). Pengaruh Intellectual Capital TerhadapKinerja Keuangan Perusahaan Perbankan di Indonesia. Tesis pada Program PascasarjanaUniversitas Diponegoro, Semarang.

Wirdaningsih, W., \& Mardhatillah, M. (2016). Penerapan Media Audio-Visual Terhadap Keaktifan Pada Materi Hubungan Antara Sumber Daya Alam Dengan Lingkungan Siswa Kelas IV SD Negeri Pasi Teungoh Kecamatan Kaway XVI. Bina Gogik: Jurnal Ilmiah Pendidikan Guru Sekolah Dasar, 3(2). 